\title{
Ameliorative role of misoprostol on hematological and biochemical parameters of male rats' treated with ciprofloxacin
}

\author{
Orass Saad Khayoon \\ ${ }^{1}$ Department of Physiology, pharmacology and biochemistry, College of Veterinary medicine, \\ University of Thi-Qar \\ Email: oras-s@utqu.edu.iq
}

\begin{abstract}
Ciprofloxacin (CPX) is one of the most frequently used fluoroquinolone drugs used in treatment of infections caused by gram negative microbes. The currant aim of this study to ensure the defense action of misoprostol (MP) against undesirable effect induced by ciprofloxacin. Thirty white male rats were divided into three equal groups (first group: control group, second group: Ciprofloxacin group, which given ciprofloxacin at a dose $100 \mathrm{mg} / \mathrm{kg} / \mathrm{day}$ orally for 14 days, and third group: ciprofloxacin and misoprostol group, which given combination of ciprofloxacin at a dose $100 \mathrm{mg} / \mathrm{kg} /$ day orally and misoprostol at a dose $200 \mu \mathrm{g} / \mathrm{kg} /$ day orally for 14 days. After 14 day of treated, the rats were scarified, blood taken for measured RBC count, HB concentration, platelet number. WBC count and liver enzymes (ALT, AST, ALP). The results indicated a significant decrease $(p<0.05)$ of RBC, Hb, platelets and WBC in male rats treated with CPX compared with control group, also liver enzymes were increased significantly $(p<$ 0.05 ) in CPX group compared with control group, while co-administration of misoprostol with CPX administration produce improving effects on hematological parameters and liver enzymes when compared with first and second group.

Conclusion: ciprofloxacin induced oxidative effect that can be removed by misoprostol.
\end{abstract}

\section{Introduction}

Ciprofloxacin (CPX) is an antibacterial agent; it was synthetized by Bayer at the end of 1982. Ciprofloxacin is considering as a second generation of fluoroquinolons group which has highly effective against gram negative bacteria (Sub and Lorber, 1995). It was widely used in the treatment of urinary, bone and soft tissue, skin, respiratory tract, reproductive tract, gastro-intestinal infections (Hooper and wolfson, 1985). It can be given orally and it well tissue penetration and induced its antibacterial action (Liu and Wong, 1999). Ciprofloxacin like other quinolones contains ciprofloxacin hydrochloride which responsible for induces many disturbances like hepatotoxicity, cholestatic jaundice, bilirubenemia, with increase of ALP, AST, ALT and prolonged time of prothrombin (Hirch and Lundquist, 2009). Wayers et al. (2002) found increased in lipid hydroperioxide (COOH) in the liver of mice treated with ciprofloaxacin, this indicate that the ciprofloxacin induced stress in the liver.

Misoprostol (MP) is a synthetic analogue to endogenous hormone prostaglandin E1 (PGE1), used mainly in the treatment of peptic ulcer that related with administration of NSAIDs (Park et al., 2009). The effect of MP in scavenger of ROS has gained highly interest within the past few years (Salam et al., 2009). In addition, MP has been used as antiapoptotic and cytoprotective effects (Yang et al., 2002; Sostres et al., 2010). Ozer et al., (2011), investigate the effect of MP on kidney disturbance induced by $\mathrm{CP}$, which enhanced lipid peroxidation and induced decrease in the antioxidant enzymes of the kidney.

The present study was aimed to investigate the ameliorative role of misoprostol on hematological and biochemical parameter of male rats' treated with ciprofloxacin 


\section{Material and Methods}

Thirty albino wistar male rats weighing between 175- $200 \mathrm{~g}$ were kept in wooden cages under standard conditions ( $28^{\circ} \mathrm{C}$ ambient temperature with 12 hours light-dark cycle). The first group was considered as control group, the second group was administered only with ciprofloxacin of $100 \mathrm{mg} / \mathrm{kg} /$ day (AL-Rikaby et al., 2016 ) for 14 days orally and the third group was administered orally with ciprofloxacin of $100 \mathrm{mg} / \mathrm{kg} / \mathrm{BW} /$ day plus misoprostol of $200 \mu \mathrm{g} / \mathrm{kg} / \mathrm{BW} /$ day after one hour (Nasr, 2013) for 14 days orally. On the last day of administration, feeds were withdrawn from the rats twelve hours to the time of sacrifice. The rats were euthanized with chloroform, cardiac punctured by $10 \mathrm{ml}$ disposable syringe of $22 \mathrm{G}$ needles (Parasuraman et al., 2010) and one ml of blood collected into sample tubes containing heparin for hematological analysis and the remaining volume the blood putting into plain tube without EDTA and centrifuged at $3000 \mathrm{rpm}$ for 15 minutes to obtain the serum which then transferred into Eppendorf tubes and stored at -20 ㅇ C till used for measurement of biochemical parameters like liver enzymes (Gray et al., 2003).

\section{Results}

The results in table (1) showed a significant decreased $(P \leq 0.05)$ in, $R B C$ count, $H b$ level, platelets number and WBC count in the second group when compared with the first group. Administration of misoprostol with ciprofloxacin in the third group ameliorated the effects of ciprofloxacin on the above blood parameters but there were non-significant elevated in RBC count and plat. number, and a significant elevated $(P \leq 0.05)$ in $\mathrm{Hb}$ level, and WBC count when compared with first group.

Table 1: Ameliorative role of misoprostol on heamatological parameters of male rats treated with ciprofloxacin

\begin{tabular}{|c|c|c|c|c|}
\hline Groups & $\mathbf{R B C} \times \mathbf{1 0} \mathbf{1} / \boldsymbol{\mu} \mathbf{L}$ & $\mathbf{H b}(\mathbf{g} / \mathbf{d L})$ & Plat. $\times \mathbf{1 0} \mathbf{3}^{\mathbf{3}} / \boldsymbol{\mu L}$ & $\mathbf{W B C}$ \\
\hline G-1 & $5.44 \pm 0.8 \mathrm{a}$ & $10.36 \pm 0.07 \mathrm{a}$ & $501.86 \pm 0.67 \mathrm{a}$ & $4.69 \pm 0.086 \mathrm{a}$ \\
\hline G-2 & $4.22 \pm 0.9 \mathrm{~b}$ & $7.33 \pm 0.06 \mathrm{c}$ & $363.34 \pm 12.3 \mathrm{~b}$ & $3.22 \pm 0.08 \mathrm{c}$ \\
\hline G-3 & $5.39 \pm 0.1 \mathrm{a}$ & $9.42 \pm 0.12 \mathrm{~b}$ & $519.54 \pm 7.58 \mathrm{a}$ & $4.28 \pm 0.11 \mathrm{~b}$ \\
\hline LSD & 0.86 & 0.85 & 154.56 & 0.095 \\
\hline
\end{tabular}

The obtained results in Table (2) revealed that the administration of CPX cause a significant increase $(P<0.05)$ in serum ALT, AST and ALP levels when compared with the levels of normal rats. This elevation in serum level of the liver enzymes were reduced significantly $(P<0.05)$ after administration of MP in dose of $200 \mu \mathrm{g} / \mathrm{kg} / \mathrm{BW}$ compared with control animals.

Table 2: Ameliorative role of misoprostol on biochemical parameters of male rats treated with ciprofloxacin

$M \pm S E$

\begin{tabular}{|c|c|c|c|}
\hline Groups & ALT(U/L) & AST(U/L) & ALP (IU/L) \\
\hline G-1 & $8.62 \pm 0.19 \mathrm{c}$ & $23.81 \pm 0.16 \mathrm{c}$ & $32.22 \pm 0.23 \mathrm{c}$ \\
\hline G-2 & $16.16 \pm 0.25 \mathrm{a}$ & $42.5 \pm 0.20 \mathrm{a}$ & $49.96 \pm 1.48 \mathrm{a}$ \\
\hline G-3 & $8.94 \pm 0.23 \mathrm{~b}$ & $26.92 \pm 0.25 \mathrm{~b}$ & $39.54 \pm 0.7 \mathrm{~b}$ \\
\hline LSD & 0.53 & 0.44 & 9.21 \\
\hline & & & \\
\hline
\end{tabular}


ISSN Onlin:2708-9347, ISSN Print: 2708-9339 Volume 9, Issue 1 (2020) PP 38-43

https://jam.utq.edu.iq/index.php/main Doi: https://doi.org/10.54174/UTJagr.Vo9.N1/04

\section{Discussion}

Ciprofloxacin is one of the fluoroquinolones class, which are mostly prescribed in both humans and animals. This class of antibiotics is the first line drug for several infections including infections of the reproductive and urinary system and respiratory infection (Liu and Mulholland, 2005; MacDougall et al., 2005).

CPX has been readily prescribed for treatment of gram negative bacteria in recent times with efficacy in respiratory, urinary tract, gastrointestinal and abdominal infections (Oliphant and Green, 2002; Kumar et al., 2011).

In the present study administration of ciprofloxacin result in a significant decreased in erythrocytes count, hemoglobin concentration, platelet number, and in leukocytes counts, these results are agreed with (Stiene-Martin et al., 1998; Oridupa et al., 2013; Priyadharshini, 2013; Edem et al., 2016). The reduction in red blood cell count and hemoglobin level may be due to suppression of bone marrow function which may result in anemia. Anemic condition which may be a consequence of iron deficiency (Palande, 2011) and unavailability (Gupta, 2014) may be as a result of coagulation of iron with ciprofloxacin thereby rendering the ion insufficient (Borcherding et al., 1996). The depletion of iron reduces the synthesis of hemoglobin in the bone marrow which in turn decreases the red blood cell counts. Also the significant decrease in red blood cell counts and hemoglobin was obtained by AL- Nahari (2014) who studied the physiological and hematological changes induced by the administration of ciprofloxacin in mice and found marked decline in RBC count and $\mathrm{Hb}$ concentration.

Packman, 2001, suggested other mechanisms that have been postulated for drug-mediated anemia. The first mechanism is the hapten-drug adsorption mechanism, means attachment of the drug with the membrane of RBC, and attachment of anti-drug antibody to the membrane-bound drug, which opsonizes the cells for destroyed by splenic macrophages. Second mechanism, is the a trimolecular complex may be formed which composes of the drug, RBC membrane antigen and an antibody which recognises the complex formed by the drug and RBC membrane. These two mechanisms require the presence of the drug, while the third mechanism does not require the drug for destruction of RBC. Some drugs directly stimulate formation of true autoantibodies which are same as those seen in autoimmune haemolytic anaemia, with increased synthesis of lymphocytes (Packman, 2001; Pierce and Nester, 2011).

On the other hand the study revealed that there was a slight decrease in white blood cell suggesting a disorder in the bone marrow which hampered the production of white blood cells. In this respect, the findings agreed with those obtained by Priyadharshini (2013) who reported the decrease in white blood cell count in rats during administration of ciprofloxacin. Reduced platelet count as seen in all the dosage administered may be caused by disorder in platelet production or conditions in which platelets are used up (consumed) or destroyed faster than normal and this may result to thrombocytopenia which could lead to impairment of the normal physiological activities of the system (Stiene-Martin et al., 1998).

Also the results are showed a marked increase in AST, ALT and ALP in rats treated with ciprofloxacin. This is agreed with the finding by (Orman et al., 2001; Edem et al., 2016), showed that CPX induced hepatic dysfunction manifestation with marked elevated in liver enzymes (AST, ALT and ALP). Bhagirath, (2008) demonstrated that ciprofloxacin induced hepatotoxicity in most patient treated with therapeutic doses is characterized by elevated levels of AST, ALT and ALP. This is supported by Hirsch and Lundquist (2009), who found that ciprofloxacin, has a potential hepatotoxic agent.

The mechanism of hepatic injury that occurs by ciprofloxacin is not well understood. Some studies suggested that the ciprofloxacin generates free oxidative radical could cause oxidative stress in the liver, result in liver damage. This is supported by study by Weyers et al., 2002, who investigated that lipid hydroperoxide (LOOH) is increased by ciprofloxacin in mice liver, which is a marker of induced oxidative stress, this oxidative stress was decrease or inhibited released by ascorbic acid. The synthesis oxidative radicals due to administration of CPX may lead to 
decrease of protein content in the liver cell which results in decreased in nucleic acids and finally damage of DNA, as a result of this effect, the number of mitochondria is decreased due to degeneration of it, which is responsible for energy supply. (Pino et al., 1991). This supported that the antibacterial activity of CPX by marked inhibition of bacterial DNA topoisomerase (Gellert et al., 1981; Crumplin et al., 1984; Gilman et al., 1990).

The results show the benefit effect of MP on the liver enzymes. These results are agreed with Salam et al., 2009, who found that the treatment with misoprostol protects against hepatocellular necrosis induced by $\mathrm{CCl}_{4}$, and agreed with Ozer et al., 2011 and Nasr et al., 2013, who findings that the MP has antioxidant activity renal toxicity in rats induced by $\mathrm{CP}$, it cause decreased MDA level with increased production of antioxidant enzymes as SOD and CAT in the kidney tissue when compared to the normal rats. Thus MP considerable as scavenger of ROS scavenger (Ozer et al., 2011).

A combination of two drugs misoprostol and ciprofloxacin in third treated group produced a significant decrease in liver enzymes when compared with the ciprofloxacin-treated rats. Treated with MP cause improvement of liver enzymes, which might be cause stabilizing effect on the hepatocyte cell membrane, result in prevents AST, ALT, and bilirubin leakage into the extracellular fluid (Ajith et al., 2007). MP enhance regenerating of the destroy liver cell (Salam et al., 2009).

It has been reported that, the antioxidant effect of misoprostol did not limit lipid peroxidation in vivo and did not protect against the oxidant injury of tert-butylhydroperoxide in vitro (Ozer et al., 2011). Conversely, the protective effect of MP might be due to hemodynamic factors, increased regenerative capacity of epithelial cells, or an inflammatory response through a cytoprotective effect and reduction of the immune-mediated liver damage. (Brunton et al., 2006; Asci et al., 2011). Moreover, misoprostol was shown to block the apoptosis generated through the toxic D-galactosamine (Ranchal et al., 2006).

In conclusion, this experiment has shown that ciprofloxacin exert distrubance in hematological parameters and some liver enzymes in albino male rats, which can modulation by administration of misoprostol.

\section{References}

1. Ajith, T.A.; Usha, S. and Nivitha, V. (2007). Ascorbic acid and alpha-tocopherol protect anticancer drug cisplatin induced nephrotoxicity in mice: a Comparative study. Int J Clin Chem., 375: 82-86.

2. AL- Nahari, H. (2014). Physiological and Hematological Changes Induced by the Administration of Ciprofloxacin in Mice. International Review of Applied Sciences, 1(1): 12- 16.

3. AL-Rikaby, A.A.; Ghadhban, R.F. and Majeed, S.K. (2016). The effects of ciprofloxacin on male rabbits: Biochemical and histopathological study. AL-Qadisiya Journal of Vet. Med. Sci. Vol. 15.

4. Asci, H.; Ozer, M.K.; Calapoglu, M.; Savran, M.; Oncu, M.; Yesilot, S.; Candan, I.A.; Klac, E. and Cicek, E. (2011). Effect of misoprostol on methotrexate-induced hepatic and renal damages. J Bio Life Sci., 2: 32-37.

5. Bhagirath, M.K. (2008). A case report of high suspected Ciprofloxacin-induced heatotoxicity. Tur. J. Gastro. 19(3):204-206.

6. Borcherding, S.M., Stevens, R., Nicholas, R.A., Corley, C.R. and Self, T. (1996). Quinolones: A Practical Review of Clinical Uses, Dosing Considerations and Drug Interactions. Journal of Family Practice, 42: 69-78.

7. Brunton, L.L.; Lazo, J.S. and Parker, K.I. (2006). Goodman and Gilman's the pharmacological basis of therapeutics. New York: Mc Graw Hill Companies; 2006.

8. Crumplin, G.C.; Kenwright, M. and Hirst, T. (1984). Investigation into the Mechanism of Action of Antibacterial Agent Norfloxacin. Journal of Antimicrobial Chemotherapy., 13(1B): 9-23.

9. Edem, E.O.; Etim, O.E.; Akpan H.D. and Akpan, E.J. (2016). Effect of Ciprofloxacin on Hematological and Biochemical Parameters in Albino Rats. Nigerian Journal of Pharmaceutical and Applied Science Research, 5(1):61-64.

10. Gray, A.; Rockwood, R. and Steven, I. (2003). Species comparison of Met Hemoglobin reductase. Baskin Experimental Biology and Medicine., 228(1):79- 83. 
11. Gellert, M. (1981). DNA Topoisomerase. Annual Review of Biochemistry.,(50):879-910.

12. Gilman, A.G.; Rall, T.N.; Nies, A.S. and Taylor, P. (1990). The Pharmacological Basis of Therapeutics.. 8th Edition, Pergamon, New York, 1057-1060.

13. Gupta, C.P. (2014). Role of Iron (Fe) in Body. Journal of Applied Chemistry. 7(2): 38-46.

14. Hirsch, A. and Lundquist, L.M. (2009). Ciprofloxacin-induce hepatotoxcity resolved with lovefloxcin. Hosp. Pharm., 44(11):978-983.

15. Hirsh, A. and Lundquist, I. B. (2009). Therapeutic effects of ciprofloxacin on the pharmacokinetics of carbamezepine in healthy adult. Journal of Pharmaceutics, 24(I):63-68.

16. Hooper DC, wolfson JS (1985). The fluoroquinolones pharmacology clinical uses toxicities in human. Antrimicro. Agen. Chem. 28(5): 716-721.

17. Kumar, N.S., Dhivya, D. and Vijayakumar, B. (2011). A Focus on Quinolones and its Medical Importance. International Journal of Novel Trends in Pharmceutical Sciences, 1(1): 23-29.

18. Liu, H. and Mulholland, S.G. (2005). Appropriate antibiotic treatment of genitourinary infections in hospitalized patients. Am. J. Med. 118 Suppl 7A (7), 14S-20S.

19. Liu, Q. and Wong, J.C. (1999). Similarity in the catalysis of DNA break age and rejoining by type IA and IIA DNA topoisomerase. Proc. Nalt. Acad. Sci. USA. 96:881-886

20. MacDougall, C.; Guglielmo, B.J.; Maselli, J. and Gonzales, R. (2005). Antimicrobial drug prescribing for pneumonia in ambulatory care. Emerg. Infect. Dis. 11 (3), 380-384.

21. Nasr, A.Y. (2013). Effect of Misoprostol on Ultrastructural Changes of Renal Tissues in Cisplatin-Treated Adult Rats. J Cytol Histol. Volume $4 \bullet$ Issue 3.

22. Nasr,A.Y. (2013). Morphological, biochemical, histological, and ultrastructural protective effects of misoprostol on cisplatin induced-hepatotoxicity in adult male rats. Saudi Med. J. Vol. 34 (12).

23. Oliphant, C.M. and Green, G.M. (2002). Quinolones: A Comprehensive Review. American Academic Family Physicians, 66(3):455-464.

24. Oridupa, A.O.; Omobowale, T.O.; Abiola, J.O.; Azeez, I. O. and Ajibade, T.0. (2013). Effect of Ciprofloxacin and Levofloxacin on haematological parameters of dogs Afr. J. Biomed. Res., 16. $25-29$.

25. Orman, S.E.; Conjevaram, H.S. and Rochen, J. (2001). Clinical and histological features of fluoroquin-dones induce liver. Injury. Clin. Gastrol. Hepatol. 3: 517-523.

26. Ozer, M.K.; Asci, H.; Oncu, M.; Calapoglu, M.; Savran, M.; Yesilot, S.; Candan, I.A. and Cicek, E. (2011). Effects of misoprostol on cisplatin-induced renal damage in rats. Food and Chemical Toxicology., 49 (7): 1556-1559.

27. Packman C.H. (2001). Drug-related immune haemolytic anemia. In: Williams Hematology, Ernest Beutler, Marshall A. Lichtman, Barry S. Coller, Thomas J. Kipps, and Uri Seligsohn (eds), Chapter 57, McGraw-Hill Publishers.

28. Palande,L.(2011).LowLiverEnzymes.In:http://www.buzzle.com/articles/low-liverenzyme.html.

29. Park, H.R.; Ju, E.J.; Jo, S.K.; Jung, U.; Kim, S.H. and Yee, S.T. (2009). Enhanced antitumor efficacy of cisplatin in combination with HemoHIM in tumor-bearing mice. BMC Cancer 9: 85.

30. Parasuraman, S.; Raveendran, R. and Kesavan, R. (2010). Blood sample collection in small laboratory animals. J Pharmacol Pharmacother., 1(2):87-93.

31. Pierce A. and Nester T. (2011). Pathology consultation on drug-induced hemolytic anemia. Am. J. Clin. Path. 136, 7-12.

32. Pino, A.; Maura, A.V. and Masciangelo, L. (1991). Evaluation of DNA Damage Induced by Norfloxacin in Liver and Kidney of Adult Rats and Fetal Tissues after Transplacental Exposure. Mutation Research., (264):81-85.

33. Priyadharshini, K.M. (2013). Ciprofloxacin Induced body weight and Haematological Changes in Rats and Anti-oxidant Vitamin A, C and E as Rescue Agents. International Journal of Engineering Science Invention, $2: 2$. 
34. Ranchal, I.; Gonzalez, R. and Lopez-Sanchez, L.M. (2006). The differential effect of PGE1 on Dgalactosamine-induced nitosative stress and cell death in primary culture of human hepatocytes. Prostaglandins Other Lipid Mediat 2006; 79: 245-259.

35. Salam, O.M.; Sleem, A.A.; Omara, E.A. and Hassan, N.S. (2009). Hepatoprotective effects of misoprostol and silymarin on carbon tetrachloride-induced hepatic damage in rats. Fundam Clin Pharmacol., 23(2):17988.

36. Sostres, C.; Gargallo C.J.; Arroyo, M.T.; Lanas, A. (2010). Adverse effects of nonsteroidal antiinflammatory drugs (NSAIDs, aspirin and coxibs) on upper gastrointestinal tract. Best Pract Res Clin Gastroenterol 24: 121-132.

37. Stiene-Martin, E.A.; Lotspeich-Staininger, C.A. and Koepia, J.A. (1998). Clinical Haematology; Principles, Procedure and Correlations. 2nd Edition. Lippincolt, Philadelphia, New York.: 963.

38. Sub B and Lorber B (1995). Quinolones. Med. Clin. 79: 869-894.

39. Wayers, R. W., Johnson, C. E. and Carlin, S. A. (2002). Cefixime compared with amoxiallin for treatment of acute otitis. Medical Journal of Pediatrics, 1:117-212.

40. Weyers, I.U.; Hugo, G.O. and Nora, B.G. (2002). Ciprofloxacin Increases Hepatic and Renal Lipid Hydroperoxide Levels in Mice, Biocell., 26(2): 225-228.

41. Yang, H.; Majno, P.; Morel, P.; Toso, C.; Triponez, F.; Oberholzer, J.; Mentha, G. and Lou, J. (2002). Prostaglandin $\mathrm{E}(1)$ protects human liver sinusoidal endothelial cell from apoptosis induced by hypoxia reoxygenation. Microvasc Res., 64(1): 94-103. 